\title{
Sugar-fermenting yeast as an organic source of carbon dioxide to attract the malaria mosquito Anopheles gambiae
}

Renate C Smallegange ${ }^{1 *}$, Wolfgang H Schmied ${ }^{1}$, Karel J van Roey ${ }^{1}$, Niels O Verhulst ${ }^{1}$, Jeroen Spitzen ${ }^{1}$, Wolfgang R Mukabana ${ }^{2,3}$, Willem Takken ${ }^{1}$

\begin{abstract}
Background: Carbon dioxide $\left(\mathrm{CO}_{2}\right)$ plays an important role in the host-seeking process of opportunistic, zoophilic and anthropophilic mosquito species and is, therefore, commonly added to mosquito sampling tools. The African malaria vector Anopheles gambiae sensu stricto is attracted to human volatiles augmented by $\mathrm{CO}_{2}$. This study investigated whether $\mathrm{CO}_{2}$, usually supplied from gas cylinders acquired from commercial industry, could be replaced by $\mathrm{CO}_{2}$ derived from fermenting yeast (yeast-produced $\mathrm{CO}_{2}$ ).

Methods: Trapping experiments were conducted in the laboratory, semi-field and field, with An. gambiae s.s. as the target species. MM-X traps were baited with volatiles produced by mixtures of yeast, sugar and water, prepared in $1.5,5$ or $25 \mathrm{~L}$ bottles. Catches were compared with traps baited with industrial $\mathrm{CO}_{2}$. The additional effect of human odours was also examined. In the laboratory and semi-field facility dual-choice experiments were conducted. The effect of traps baited with yeast-produced $\mathrm{CO}_{2}$ on the number of mosquitoes entering an African house was studied in the MalariaSphere. Carbon dioxide baited traps, placed outside human dwellings, were also tested in an African village setting. The laboratory and semi-field data were analysed by a $\chi^{2}$-test, the field data by GLM. In addition, $\mathrm{CO}_{2}$ concentrations produced by yeast-sugar solutions were measured over time.

Results: Traps baited with yeast-produced $\mathrm{CO}_{2}$ caught significantly more mosquitoes than unbaited traps (up to $34 \mathrm{~h}$ post mixing the ingredients) and also significantly more than traps baited with industrial $\mathrm{CO}_{2}$, both in the laboratory and semi-field. Adding yeast-produced $\mathrm{CO}_{2}$ to traps baited with human odour significantly increased trap catches. In the MalariaSphere, outdoor traps baited with yeast-produced or industrial $\mathrm{CO}_{2}+$ human odour reduced house entry of mosquitoes with a human host sleeping under a bed net indoors. Anopheles gambiae s.s. was not caught during the field trials. However, traps baited with yeast-produced $\mathrm{CO}_{2}$ caught similar numbers of Anopheles arabiensis as traps baited with industrial $\mathrm{CO}_{2}$. Addition of human odour increased trap catches.
\end{abstract}

Conclusions: Yeast-produced $\mathrm{CO}_{2}$ can effectively replace industrial $\mathrm{CO}_{2}$ for sampling of An. gambiae s.s.. This will significantly reduce costs and allow sustainable mass-application of odour-baited devices for mosquito sampling in remote areas.

\section{Background}

Carbon dioxide $\left(\mathrm{CO}_{2}\right)$, a major constituent of vertebrate breath, plays an important role in the host-seeking process of mosquitoes [1-6]. Therefore, the compound is commonly added to traps used for mosquito surveillance

\footnotetext{
* Correspondence: renate.smallegange@wur.nl

'Laboratory of Entomology, Wageningen University, P.O. Box 8031, 6700 EH, Wageningen, The Netherlands

Full list of author information is available at the end of the article
}

[7-9]. Among malaria vectors, opportunistic, zoophilic as well as anthropophilic mosquito species are affected by $\mathrm{CO}_{2}$ [2,4,6,10-13]. In Anopheles gambiae sensu stricto, an important vector of human malaria in sub-Saharan Africa and considered to be highly anthropophilic [14], $\mathrm{CO}_{2}$ augments the attractiveness of human odour $[6,12]$ and it is an essential cue to lure the female mosquitoes into the vicinity of mosquito traps [5,13].

\section{Ciomed Central}

(c) 2010 Smallegange et al; licensee BioMed Central Ltd. This is an Open Access article distributed under the terms of the Creative Commons Attribution License (http://creativecommons.org/licenses/by/2.0), which permits unrestricted use, distribution, and reproduction in any medium, provided the original work is properly cited. 
Even though $\mathrm{CO}_{2}$ has a positive effect on the number of mosquitoes that are caught by suction traps, in resource-poor areas, like sub-Saharan Africa, it is hard to obtain $\mathrm{CO}_{2}$ sources that are reliable, cheap, easy to manage and durable. Propane-powered traps that produce $\mathrm{CO}_{2}$ [15] are difficult to obtain, heavy and expensive. The same is true for industrially-acquired $\mathrm{CO}_{2}$, which, packaged in steel cylinders, has the advantage that the release rate of $\mathrm{CO}_{2}$ can be regulated, but leakage at the connections may occur. In addition, flow meters may be costly and sensitive to dust and high humidity. Dry ice, an alternative source of $\mathrm{CO}_{2}$, is cheap and easier to handle than pressurized $\mathrm{CO}_{2}$ cylinders, but is difficult to obtain and transport in the tropics, besides the need for replenishment on a regular basis. Moreover, dry ice has the disadvantage that the release rate of $\mathrm{CO}_{2}$ is highly variable and diminishes over time $[2,16]$.

Saitoh et al [16] developed an easy and cheap method to produce $\mathrm{CO}_{2}$ by using a yeast-sugar solution in plastic bottles. Under anaerobic conditions, yeast (synonym for strains of Saccharomyces cerevisiae or baker's yeast) converts sugar into $\mathrm{CO}_{2}$ and ethanol [17-20]. In Japan, traps baited with yeast-generated $\mathrm{CO}_{2}$ caught higher numbers of Aedes and Culex spp. than unbaited traps. The objective of the present study was to investigate, under laboratory, semi-field and African field conditions, whether this method is valuable to lure An. gambiae s.s. females towards suction traps, as an alternative for industrial-acquired $\mathrm{CO}_{2}$.

\section{Methods \\ Mosquitoes}

Female mosquitoes used for the laboratory experiments were collected from a culture of Anopheles gambiae s.s. (hereafter referred to as An. gambiae) (Suakoko strain) kept at Wageningen University, The Netherlands. The culture has been reared by blood-feeding on human arms since 1988. Larvae were kept in tap water and fed on Tetramin ${ }^{\circ}$ baby fish food. Pupae were collected daily and transferred to $30 \mathrm{~cm}$ cubic gauze cages for emergence. Adult mosquitoes were kept at $27^{\circ} \mathrm{C}, 80 \% \mathrm{RH}$ and a photo:scotophase of 12:12 h, respectively. A $6 \%$ glucose solution was provided ad libitum on filter paper.

The semi-field experiments were conducted using the Mbita strain of An. gambiae. The mosquitoes have been reared under ambient climatic conditions at insectaries belonging to the Thomas Odhiambo campus of the International Centre of Insect Physiology and Ecology (ICIPE) located at Mbita Point, western Kenya, since 2001. Adult insects were kept in $30 \mathrm{~cm}$ cubic gauze cages and provided with a $6 \%$ glucose solution ad libitum. Blood feeding took place on human arms. Larvae were kept in filtered water from Lake Victoria and fed on Tetramin ${ }^{\circ}$ baby fish food. Upon pupation, insects were transferred to adult cages for emergence.

The age of the female mosquitoes used for the laboratory experiments was 5-8 days; the An. gambiae females used for the semi-field experiments were 3-7 days old. The females, previously not blood-fed, were randomly collected from their cage and placed in a release cage $(\mathrm{d}=8 \mathrm{~cm}, \mathrm{~h}=20 \mathrm{~cm}$ in the laboratory experiments or $\mathrm{d}=11-13 \mathrm{~cm}, \mathrm{~h}=15 \mathrm{~cm}$ in the semi-field experiments) 16 (laboratory) respectively 8 (semi-field) h before the experiments were started. To prevent dehydration the mosquitoes were offered water-moistened cotton wool on top of the release cage.

\section{Traps}

Mosquito Magnet-X counter flow geometry traps (MMX; American Biophysics Corp., USA, [21], see also $[22,23])$, were suspended from metal or wooden stands, with the odour outlet $15 \mathrm{~cm}$ above ground level $[12,13]$. The bullet-shaped cartridges within the lower end of the odour outlet tube of the traps were removed. The electric ventilators in the MM-X traps operated on $12 \mathrm{~V}$ batteries. During the experiments performed in the MalariaSphere [24] also CDC miniature light traps (Model 512; John W. Hock Company, USA, [25]) were used. These traps were run on $6 \mathrm{~V}$ batteries (Gaston Battery Industrial Ltd, China). After removing the caught mosquitoes, each trap was cleaned with $10 \%$ ethanol.

\section{Odour stimuli}

Yeast-produced carbon dioxide was produced by mixing dry yeast (Dr. Oetker, The Netherlands, used in the laboratory experiments carried out in Wageningen or Angel Yeast Co. Ltd., China, used in the semi-field and field experiments in Kenya), sugar (Van Gilse Kristalsuiker, Suiker Unie, The Netherlands, in the laboratory experiments or Sony Sugar, South Nyanza sugar Co. Ltd., Kenya, in the (semi-)field experiments) and tap water [16] in two plastic bottles of $1.5 \mathrm{~L}$ or $5 \mathrm{~L}$, connected with each other by silicon tubing, or one plastic container of $25 \mathrm{~L}$. Mixing took place $1-1 \frac{1}{2} \mathrm{~h}$ before mosquitoes were released, at ambient temperature, until the dry yeast was dissolved. No additional stirring or mixing took place during the experiments. A $0.5 \mathrm{~L}$ respectively $1 \mathrm{~L}$ bottle was put in between the $1.5 \mathrm{~L}$ respectively $5 \mathrm{~L}$ bottles with the mixtures and the MM$\mathrm{X}$ trap to prevent foam produced by the mixtures entering the trap (Figure 1A-C). Holes were drilled into the original screw caps of the bottles and into the side of the small bottles; silicon tubing ( $7 \mathrm{~mm}$; Rubber B.V., The Netherlands) fitted through these holes to connect the bottles. The smaller bottle was connected to the MM-X trap using the original MM-X tubing (micron 


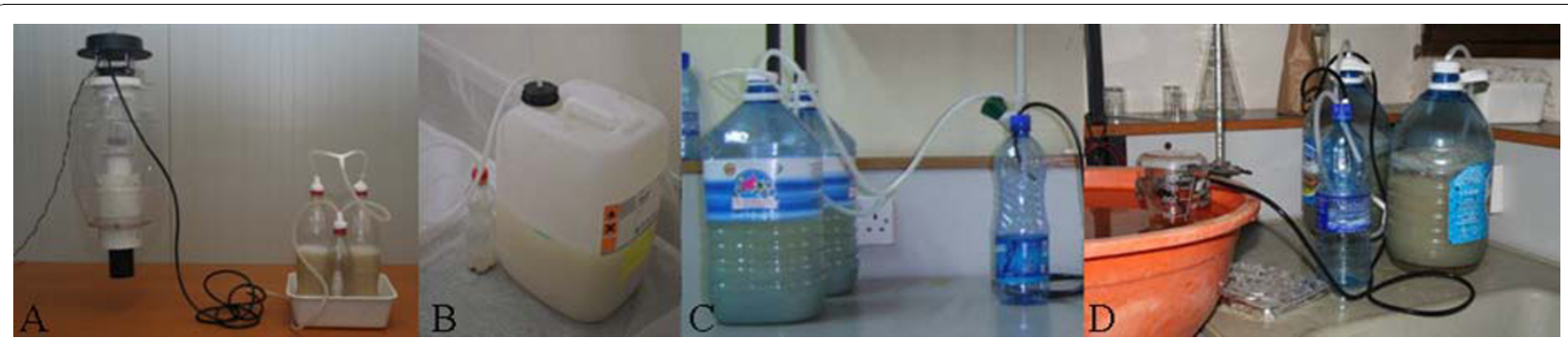

Figure 1 Pictures showing the different setups used to apply the yeast-sugar solutions and to measure the $\mathrm{CO}_{2}$ production. A. Two 1.5 $\mathrm{L}$ bottles; B. One $25 \mathrm{~L}$ container; C. Two $5 \mathrm{~L}$ bottles; $\mathrm{D}$. $\mathrm{CO}_{2}$ production measurement.

filter and orifice removed) and the Luer connection at the underside of the trap's top lid. The connections were sealed by Teflon tape and held under water to check for leakage. Several combinations of bottle size and amount of yeast, sugar and water were used. The carbon dioxide output was estimated by measuring the volume of water displaced from a submerged measuring cylinder (Table 1). For this purpose, the tubing that was attached to the MM-X traps during the mosquito trapping experiments was now led into a measuring cylinder which was held in a bucket of water (Figure 1D).

Industrial carbon dioxide ( $\geq 99.9 \%$ ) was released from pressurized gas cylinders (Linde Gas Benelux B.V., The Netherlands in laboratory experiments or Carbacid Investments Ltd., Kenya, in (semi-)field experiments) and supplied to the MM-X traps through silicon tubing (Ø $7 \mathrm{~mm}$; Rubber B.V., The Netherlands). The Luer connection at the underside of the trap's top lid was used to release the gas directly into the odour outlet tube of the trap. A flow meter (Sho-Rate model GT1350 or GT1355, used in laboratory and semi-field experiments; Brooks Instruments, The Netherlands) or an orifice (American Biophysics Corp., USA; used in field experiments) regulated the flow rate of $\mathrm{CO}_{2}$. During the laboratory experiments, $\mathrm{CO}_{2}$ was led through a $0.5 \mathrm{~L}$ bottle before it was released into a MM-X trap. This bottle was filled for $50 \%$ with a $10 \%$ sugar solution.

Human foot odour was released from nylon socks (40 Den, $100 \%$ polyamide, HEMA, The Netherlands) worn by WHS (laboratory experiments) or KJvR (semi-field and field experiments) for $12 \mathrm{~h}$ prior to the experiments [6,12,13,26-29]. A clean nylon sock served as a control. Socks were placed along the odour outlet tube of the MM-X trap without blocking the airflow and held in position by odourless tape $\left(3 \mathrm{M}^{\mathrm{mi}}\right.$ Double Coated Tape 400; used in laboratory experiments) or by a small metal wire (in (semi-)field experiments).

\section{Laboratory experiments}

Two MM-X traps were placed in a textile screen cage $(330 \times 250 \times 233 \mathrm{~cm}$; Howitec Netting BV, The Netherlands, [30]) at approximately $2.5 \mathrm{~m}$ distance from each other inside a climate-controlled room $\left(22.2 \pm 1.6^{\circ} \mathrm{C}\right.$ and $52.6 \pm 7.8 \% \mathrm{RH})$. The $\mathrm{CO}_{2}$ cylinder and the yeastproduced $\mathrm{CO}_{2}$ bottles were positioned within the sluice of the cage. Either two $1.5 \mathrm{~L}$ bottles or one $25 \mathrm{~L}$ container contained the yeast-sugar solution. In each $1.5 \mathrm{~L}$ bottle, $7 \mathrm{~g}$ of dry yeast and $100 \mathrm{~g}$ of refined household sugar were dissolved in $1 \mathrm{~L}$ of tap water. In the $25 \mathrm{~L}$ container, a mixture of $70 \mathrm{~g}$ of dry yeast, $1 \mathrm{~kg}$ of sugar

Table 1 Carbon dioxide flow rate $(\mathrm{ml} / \mathrm{min})$ produced by different yeast-sugar solutions

\begin{tabular}{|c|c|c|}
\hline Application & Treatment & Average $\mathrm{CO}_{2}$ production $(\mathrm{ml} / \mathrm{min} \pm$ S.D.) \\
\hline \multirow[t]{3}{*}{ laboratory } & $7 \mathrm{~g} Y+100 \mathrm{gS}+1 \mathrm{LW}$ & $3.5 \pm 2.7$ \\
\hline & $70 \mathrm{~g} \mathrm{Y}+1000 \mathrm{~g} \mathrm{~S}+10 \mathrm{LW}$ (day 1) & $14.1 \pm 13.4$ \\
\hline & $70 \mathrm{~g} Y+1000 \mathrm{~g} \mathrm{~S}+10 \mathrm{LW}$ (day 2) & $62.6 \pm 9.0$ \\
\hline \multirow[t]{6}{*}{ semi-field and field } & $17.5 \mathrm{~g} \mathrm{Y}+250 \mathrm{~g} \mathrm{~S}+2.5 \mathrm{LW}$ & $136.3 \pm 38.1$ \\
\hline & $17.5 \mathrm{~g} \mathrm{Y}+500 \mathrm{~g} \mathrm{~S}+2.5 \mathrm{LW}$ & $242.3 \pm 74.1$ \\
\hline & $17.5 \mathrm{~g} \mathrm{Y}+750 \mathrm{~g} \mathrm{~S}+2.5 \mathrm{LW}$ & $144.8 \pm 50.1$ \\
\hline & $35 \mathrm{~g} Y+250 \mathrm{~g} \mathrm{~S}+2.5 \mathrm{LW}$ & $220.2 \pm 50.1$ \\
\hline & $35 \mathrm{~g} \mathrm{Y}+500 \mathrm{~g} \mathrm{~S}+2.5 \mathrm{LW}$ & $303.5 \pm 39.7$ \\
\hline & $35 \mathrm{~g} \mathrm{Y}+750 \mathrm{~g} \mathrm{~S}+2.5 \mathrm{LW}$ & $298.1 \pm 70.2$ \\
\hline
\end{tabular}

Averages are based on measurements taken each 15 or 30 minutes between 90 and 330 minutes (laboratory experiments) or 60 and 630 minutes (semi-field and field experiments) after mixing of the yeast-sugar solutions. Measurements were done indoors during the day at ambient temperature ( $\left.22-25^{\circ} \mathrm{C}\right)$. Y: yeast; $\mathrm{S}$ : sugar; W: water. 
Table 2 Position of $\mathrm{CO}_{2}$ measurements; $\mathrm{CO}_{2}$ either produced by a yeast-sugar solution (17.5 $\mathrm{g}$ yeast+250 $\mathrm{g} \mathrm{sugar}+2 \frac{1}{2}$ $L$ water in each $5 \mathrm{~L}$ bottle) or released from a $\mathrm{CO}_{2}$ cylinder $(5 \%, 250 \mathrm{ml} / \mathrm{min})$

\begin{tabular}{llll}
\hline Measuring points & Series $\mathbf{1}$ & Series $\mathbf{2}$ & Series $\mathbf{3}$ \\
\hline 1 & inside MM-X outlet & $10 \mathrm{~cm}$ below MM-X & above MM- $X^{2}$ \\
2 & $10 \mathrm{~cm}$ below MM- $X^{1}$ & $30 \mathrm{~cm}$ from MM-X & $30 \mathrm{~cm}$ from MM-X \\
3 & $200 \mathrm{~cm}$ from MM- $X^{1}$ & $200 \mathrm{~cm}$ from MM-X & $200 \mathrm{~cm}$ from MM-X \\
\hline
\end{tabular}

${ }^{1}$ Measuring point positioned $5 \mathrm{~cm}$ above ground level.

${ }^{2}$ Measuring point positioned $100 \mathrm{~cm}$ above ground level.

and $10 \mathrm{~L}$ of tap water was prepared. In contrast to the 1.5 L bottles, which were used during a single experiment only, the $25 \mathrm{~L}$ container was used during two consecutive days without adding additional yeast, sugar or water. During the time it was not used, the container was closed and stored at room temperature. Worn socks were used to test the effect of human emanations on the attractiveness of yeast-produced $\mathrm{CO}_{2}$. The flow rate of industrial $\mathrm{CO}_{2}$ was set at $15 \mathrm{ml} / \mathrm{min}$, a flow rate within the range (up to $20 \mathrm{ml} / \mathrm{min}$ ) that was previously measured to be produced by two $1.5 \mathrm{~L}$ bottles each containing a mixture of $7 \mathrm{~g}$ of dry yeast, $100 \mathrm{~g}$ sugar and $1 \mathrm{~L}$ of tap water.

Experiments were conducted in the last $4 \mathrm{~h}$ of the dark phase when $A n$. gambiae is normally searching for a blood host [31-33]. For each replicate, 50 mosquitoes were released from the centre of the screen cage and left in it for $4 \mathrm{~h}$. After this period, the release cage and the traps were closed, the mosquitoes killed by freezing, and counted. The dual-choice experiments conducted are listed in Table 3 . Treatments were alternated between the two positions to rule out any positional effect. In addition, experiments with two unbaited MM$\mathrm{X}$ traps were conducted to test for positional effects. Each dual-choice experiment was replicated 6-8 times.
Surgical gloves were worn by the operator to avoid contamination of equipment with human volatiles.

\section{Semi-field experiments General}

The semi-field experiments were conducted under ambient temperature and humidity $\left(26.6 \pm 0.9^{\circ} \mathrm{C}\right.$ and $92.1 \pm 8.9 \% \mathrm{RH})$ at the Thomas Odhiambo campus of ICIPE, Mbita Point, Kenya. Each semi-field experiment started at 9:30 pm by connecting the $\mathrm{CO}_{2}$ tubing and powering the traps, followed by releasing the mosquitoes. At 6:30 am the following morning the experiments were terminated by closing the traps and disconnecting the carbon dioxide and power supplies. The MM-X traps and collection bags of the CDC traps were placed in a freezer to kill the caught mosquitoes prior to counting. In addition, at 11 am the number of mosquitoes resting inside the house in the MalariaSphere was determined by way of actively searching for mosquitoes. In dual-choice MM-X experiments treatments were alternated between the two positions to rule out any positional effect. In addition, experiments with two unbaited MM-X traps were conducted to test for positional effects. Surgical gloves were worn to avoid contamination of equipment with human volatiles.

Table 3 Effect of yeast-produced $\mathrm{CO}_{2}$ on trap catches during laboratory experiments

\begin{tabular}{|c|c|c|c|c|c|c|}
\hline \multirow[t]{2}{*}{ Treatment } & \multirow[t]{2}{*}{ Control } & \multicolumn{2}{|c|}{$\begin{array}{c}\text { Total number } \\
\text { caught }\end{array}$} & \multirow[t]{2}{*}{$\chi^{2}$-test } & \multirow[t]{2}{*}{$\mathbf{N}$} & \multirow[t]{2}{*}{$\begin{array}{l}\text { Mean } \% \\
\text { caught }( \pm \text { sem })^{1}\end{array}$} \\
\hline & & $\mathrm{T}$ & C & & & \\
\hline no odour & no odour & 19 & 27 & $P=0.24$ & 297 & $15.5 \pm 3.0$ \\
\hline worn sock & clean sock & $\underline{96}$ & 21 & $P<0.001$ & 277 & $41.6 \pm 7.9$ \\
\hline yeast $\mathrm{CO}_{2}(7 \mathrm{~g})$ & no odour & $\overline{186}$ & 29 & $P<0.001$ & 279 & $77.0 \pm 7.3$ \\
\hline yeast $\mathrm{CO}_{2}(7 \mathrm{~g})$ & ind. $\mathrm{CO}_{2}(15 \mathrm{ml} / \mathrm{min})$ & $\overline{103}$ & 51 & $P<0.001$ & 298 & $51.6 \pm 8.5$ \\
\hline yeast $\mathrm{CO}_{2}(7 \mathrm{~g})+$ worn sock & worn sock & $\underline{96}$ & 62 & $P=0.007$ & 278 & $55.5 \pm 12.1$ \\
\hline yeast $\mathrm{CO}_{2}(70 \mathrm{~g})+$ worn sock & worn sock & 207 & 93 & $P<0.001$ & 371 & $78.8 \pm 10.8$ \\
\hline
\end{tabular}

Yeast $=$ yeast-produced (either $7 \mathrm{~g}$ yeast $+100 \mathrm{~g}$ sugar $+1 \mathrm{~L}$ water in each $1.5 \mathrm{~L}$ bottle or $70 \mathrm{~g}$ yeast+1 $\mathrm{kg}$ sugar $+10 \mathrm{~L}$ water in a $25 \mathrm{~L}$ container).

Ind. = industrial $(15 \mathrm{ml} / \mathrm{min})$.

$\mathrm{T}=$ treatment.

$\mathrm{C}=$ control.

$\mathrm{N}=$ total number of mosquitoes released.

${ }^{1}$ Mean percentage caught expressed as the number of female mosquitoes caught in the two MM-X traps together divided by the number of mosquitoes that flew out of the release cage.

Underlined number: significant higher catch $\left(\chi^{2}\right.$-test, $\left.\mathrm{P}<0.05\right)$. 


\section{Effect of $\mathrm{CO}_{2}$ flow rate on trap catches}

Experiments with industrial $\mathrm{CO}_{2}$ were conducted to establish the minimal $\mathrm{CO}_{2}$ flow rate needed to catch An. gambiae females using MM-X traps. For this purpose, a cage made of mosquito netting $(2 \times 2 \times 6 \mathrm{~m})$ was constructed inside a greenhouse (Cambridge Glass House Co. Ltd., UK) at Mbita Point, western Kenya. The greenhouse had a glass-panelled roof, gauze covered side walls, and sand on the floor [24,29]. Two MM-X traps were placed at opposite ends of the cage at a distance of approximately $5 \frac{1}{2} \mathrm{~m}$ of each other. Carbon dioxide was provided from a gas cylinder positioned outside the cage. During each experiment the $\mathrm{CO}_{2}$ cylinder was connected to one of the MM-X traps (for details see above). The other MM-X trap was unbaited. Five $\mathrm{CO}_{2}$ flow rates were tested: 25, 60, 100,250 and $500 \mathrm{ml} / \mathrm{min}$. These flow rates were chosen because they are commonly used to bait traps in mosquito surveillance exercises and/or are close to flow rates previously measured to be produced by the yeast-sugar solutions that had been tested in the laboratory. Each flow rate was tested four times. In each experiment 100 female mosquitoes were released from the centre of the cage.

\section{Effect of yeast-produced $\mathrm{CO}_{2}$ on trap catches}

Two MM-X traps were placed in the opposite corners of a screen-walled greenhouse $(11.4 \times 7.1 \times 2.5 \mathrm{~m}$, Cambridge Glass House Co. Ltd.) with a large mosquito-netting cage $(10 \times 6 \times 2.5 \mathrm{~m}$; mesh width $3 \mathrm{~mm})$ suspended from the ceiling to the floor (screen house; [29]). This resulted in a distance of approximately $12 \frac{1}{2}$ $\mathrm{m}$ between the traps placed at $1 \frac{1}{2} \mathrm{~m}$ from the corner. A $\mathrm{CO}_{2}$ cylinder was placed next to each trap and $\mathrm{CO}_{2}$ was led to the trap using silicon tubing (for details see above). During the experiments traps were either unbaited, baited with industrial or yeast-produced $\mathrm{CO}_{2}$ or/and a worn sock. Industrial $\mathrm{CO}_{2}$ was applied at a flow rate of 100 or $250 \mathrm{ml} / \mathrm{min}$. Yeast-produced $\mathrm{CO}_{2}$ was also applied at two different flow rates, using either a mixture of $17.5 \mathrm{~g}$ of dry yeast (Angel), $250 \mathrm{~g}$ sugar (Sony) and $2 \frac{1}{2} \mathrm{~L}$ of tap water or $35 \mathrm{~g}$ of dry yeast (Angel), $500 \mathrm{~g}$ sugar (Sony) and $2 \frac{1}{2} \mathrm{~L}$ of tap water in each $5 \mathrm{~L}$ bottle. The flow rates for industrial and yeastproduced $\mathrm{CO}_{2}$ were chosen based on the results obtained in the previously described experiments (see Table 4) and the flow rates measured to be produced by different yeast-sugar solutions (see Table 1), taking into account that temperatures are lower during the night than during the day, resulting in a lower production by the yeast-sugar solution.

In addition, the effectiveness of yeast-produced $\mathrm{CO}_{2}$ was tested $24 \mathrm{~h}$ and $48 \mathrm{~h}$ after mixing the ingredients. Each dual-choice experiment was done four times, each with 200 female mosquitoes released from the centre of
Table 4 Effect of $\mathrm{CO}_{2}$ flow rate on trap catches during screen house experiments

\begin{tabular}{|c|c|c|c|c|c|}
\hline \multirow[t]{2}{*}{$\begin{array}{r}\mathrm{CO}_{2} \text { flow rate } \\
(\mathrm{ml} / \mathrm{min})\end{array}$} & \multicolumn{2}{|c|}{$\begin{array}{c}\text { Total number } \\
\text { caught }\end{array}$} & \multirow[t]{2}{*}{$\chi^{2}$-test } & \multirow[t]{2}{*}{$\mathbf{N}$} & \multirow[t]{2}{*}{$\begin{array}{l}\text { Mean } \% \\
\text { caught }( \pm \text { sem })\end{array}$} \\
\hline & $\begin{array}{l}\text { ind. } \\
\mathrm{CO}_{2}\end{array}$ & $\begin{array}{c}\text { no } \\
\text { odour }\end{array}$ & & & \\
\hline 0 & 22 & 16 & $P=0.33$ & 200 & $19.0 \pm 3.0$ \\
\hline 25 & 86 & 64 & $P=0.07$ & 400 & $37.5 \pm 6.1$ \\
\hline 60 & $\underline{100}$ & 22 & $P<0.001$ & 400 & $30.5 \pm 8.0$ \\
\hline 100 & 177 & 42 & $P<0.001$ & 400 & $54.8 \pm 7.6$ \\
\hline 250 & 126 & 32 & $P<0.001$ & 400 & $39.5 \pm 4.9$ \\
\hline 500 & 71 & 47 & $P=0.03$ & 400 & $29.5 \pm 4.6$ \\
\hline
\end{tabular}

Ind. = industrial.

$\mathrm{N}=$ total number of mosquitoes released.

${ }^{1}$ Mean percentage caught expressed as the number of female mosquitoes caught in the two MM-X traps together divided by the number of mosquitoes that flew out of the release cage.

Underlined number: significant higher catch $\left(\chi^{2}\right.$-test, $\left.\mathrm{P}<0.05\right)$.

the screen house. See Table 5 for an overview of the experiments performed.

\section{Effect of $\mathrm{CO}_{2}$ baited traps on house entry behaviour}

The MalariaSphere described by Knols et al [24] was used to test the potential of MM-X traps baited with either industrial or yeast-produced $\mathrm{CO}_{2}$ to reduce house entry by $A n$. gambiae females [34,35]. The MalariaSphere consists of a screen-walled greenhouse $(11.4 \times$ $7.1 \times 2.5 \mathrm{~m}$, Cambridge Glass House Co. Ltd.) in which a traditional African house $(3.2 \times 2.8 \times 1.7 \mathrm{~m})$ has been built and crops planted.

During the experiments, a male African volunteer (aged 27) slept inside the house on a bed, protected by an untreated bed net. Two CDC miniature light traps were hung at a height of $140 \mathrm{~cm}$ (bottom at $80 \mathrm{~cm}$ ) above ground level beside the bed net on the foot-side end of the sleeping volunteer, with its shield touching the side of the bed net [36]. An odour-baited MM-X trap was hung outdoors under the overhanging part of the thatched roof of the house, $15 \mathrm{~cm}$ above ground level [12,13]. Either industrial $\mathrm{CO}_{2}$ at a flow rate of 100 $\mathrm{ml} /$ min or yeast-produced $\mathrm{CO}_{2}$ produced by $17.5 \mathrm{~g}$ dry yeast (Angel) $+250 \mathrm{~g}$ sugar (Sony) $+2 \frac{1}{2} \mathrm{~L}$ tap water in each $5 \mathrm{~L}$ bottle was tested. Also the effect of the addition of human emanations to $\mathrm{CO}_{2}$ was examined by putting a worn sock in the MM-X trap (see Table 6). Each treatment was tested six times, and in each experiment 200 female mosquitoes were released $5 \mathrm{~m}$ away from the house (Figure 2).

\section{Field experiments}

The field experiments were conducted in Lwanda, a rural village at an altitude of $1169 \mathrm{~m}$ above sea level in the basin region of Lake Victoria, Nyanza Province, western Kenya. The area has a main rainy season from March to May and a short rainy season from October 
Table 5 Effect of yeast-produced $\mathrm{CO}_{2}$ on trap catches during screen house experiments

\begin{tabular}{|c|c|c|c|c|c|c|}
\hline \multirow[t]{2}{*}{ Treatment } & \multirow[t]{2}{*}{ Control } & \multicolumn{2}{|c|}{$\begin{array}{l}\text { Total number } \\
\text { caught }\end{array}$} & \multirow[t]{2}{*}{$\chi^{2}$-test } & \multirow[t]{2}{*}{$\mathrm{N}$} & \multirow[t]{2}{*}{$\begin{array}{l}\text { Mean } \% \\
\text { caught }( \pm \text { sem })^{1}\end{array}$} \\
\hline & & $\mathrm{T}$ & $\mathrm{C}$ & & & \\
\hline no odour & no odour & 22 & 19 & $P=0.64$ & 800 & $5.1 \pm 0.7$ \\
\hline worn sock & clean sock & $\underline{288}$ & 48 & $P<0.001$ & 800 & $43.1 \pm 4.1$ \\
\hline yeast $\mathrm{CO}_{2}$ (17.5 g) & no odour & $\underline{250}$ & 16 & $P<0.001$ & 800 & $33.3 \pm 5.7$ \\
\hline yeast $\mathrm{CO}_{2}(35 \mathrm{~g})$ & no odour & $\underline{251}$ & 11 & $P<0.001$ & 800 & $32.8 \pm 5.1$ \\
\hline yeast $\mathrm{CO}_{2}$ (17.5 g) & ind. $\mathrm{CO}_{2}(100 \mathrm{ml} / \mathrm{min})$ & $\underline{274}$ & 190 & $P<0.001$ & 800 & $58.0 \pm 7.9$ \\
\hline yeast $\mathrm{CO}_{2}(35 \mathrm{~g})$ & ind. $\mathrm{CO}_{2}(250 \mathrm{ml} / \mathrm{min})$ & $\underline{326}$ & 244 & $P<0.001$ & 800 & $71.3 \pm 2.6$ \\
\hline yeast $\mathrm{CO}_{2}(17.5 \mathrm{~g})+$ worn sock & clean sock & $\underline{411}$ & 13 & $P<0.001$ & 800 & $53.0 \pm 12.7$ \\
\hline yeast $\mathrm{CO}_{2}(17.5 \mathrm{~g})+$ worn sock & worn sock & $\underline{581}$ & 55 & $P<0.001$ & 800 & $79.5 \pm 2.5$ \\
\hline yeast $\mathrm{CO}_{2}(17.5 \mathrm{~g})+$ worn sock & ind. $\mathrm{CO}_{2(100 \mathrm{~m} / \mathrm{min})}+$ worn sock & $\underline{342}$ & 265 & $P=0.002$ & 800 & $75.9 \pm 1.8$ \\
\hline yeast $\mathrm{CO}_{2}(17.5 \mathrm{~g}) 24 \mathrm{~h}$ & no odour & 132 & 18 & $P<0.001$ & 800 & $18.8 \pm 2.9$ \\
\hline yeast $\mathrm{CO}_{2}(17.5 \mathrm{~g}) 24 \mathrm{~h}$ & ind. $\mathrm{CO}_{2}(100 \mathrm{ml} / \mathrm{min})$ & 240 & $\underline{384}$ & $P<0.001$ & 800 & $78.0 \pm 4.7$ \\
\hline yeast $\mathrm{CO}_{2}(17.5 \mathrm{~g}) 48 \mathrm{~h}$ & no odour & 57 & 41 & $P=0.11$ & 800 & $12.3 \pm 1.9$ \\
\hline yeast $\mathrm{CO}_{2}(17.5 \mathrm{~g}) 48 \mathrm{~h}$ & ind. $\mathrm{CO}_{2}(100 \mathrm{ml} / \mathrm{min})$ & 30 & $\underline{342}$ & $P<0.001$ & 800 & $46.5 \pm 2.8$ \\
\hline
\end{tabular}

Yeast $=$ yeast-produced (either $17.5 \mathrm{~g}$ yeast $+250 \mathrm{~g}$ sugar $+2 \frac{1}{2} \mathrm{~L}$ water or $35 \mathrm{~g}$ yeast $+500 \mathrm{~g}$ sugar $+2 \frac{1}{2} \mathrm{~L}$ water in each $5 \mathrm{~L}$ bottle).

Ind. = industrial (flow rate given in $\mathrm{ml} / \mathrm{min}$ ).

$\mathrm{T}=$ treatment.

$\mathrm{C}=$ control.

$\mathrm{N}=$ total number of mosquitoes released.

${ }^{1}$ Mean percentage caught expressed as the number of female mosquitoes caught in the two MM- $X$ traps together divided by the number of mosquitoes that flew out of the release cage.

Underlined number: significant higher catch $\left(\chi^{2}\right.$-test, $\left.\mathrm{P}<0.05\right)$

to December. Experiments were conducted at the end of the short rainy season, in December 2008. Lwanda has a variety of mosquito breeding habitats [37,38].

Based on several criteria (household, location of cooking site, roof construction, vegetation around the house and all houses at walking distance from each other) four approximately similar houses in Lwanda were selected. The occupants of the houses were sleeping under bed nets. Each house was provided with a MM-X trap, a car battery and a $\mathrm{CO}_{2}$ cylinder. The MM-X traps were hung outdoors, $15 \mathrm{~cm}$ above ground level, under the overhanging thatched roof, at the window side of the house
[13]. Vaseline petroleum jelly was used around the tubing, suspension cable and electrical cables to prevent ants from reaching the mosquitoes caught in the MM-X trap.

Two series of each eight nights (i.e. two blocks of a 4 $\times 4$ Latin square) were run. In the first series the following four treatments were tested: unbaited, industrial $\mathrm{CO}_{2}$ at a flow rate of $250 \mathrm{ml} / \mathrm{min}$ (the amount of $\mathrm{CO}_{2}$ released by a human, [2]), and yeast-produced $\mathrm{CO}_{2}$ at two different flow rates, using either a mixture of $17.5 \mathrm{~g}$ of dry yeast (Angel), $250 \mathrm{~g}$ sugar (Sony) and $2 \frac{1}{2} \mathrm{~L}$ of tap water or $35 \mathrm{~g}$ of dry yeast (Angel), $500 \mathrm{~g}$ sugar (Sony)

Table 6 Effect of $\mathrm{CO}_{2}$ baited traps on house entry behaviour in the MalariaSphere

\begin{tabular}{|c|c|c|c|c|c|c|}
\hline \multirow[t]{2}{*}{ Treatment outdoors } & \multirow[t]{2}{*}{ Treatment indoors } & \multicolumn{2}{|c|}{$\begin{array}{c}\text { Total number } \\
\text { caught }\end{array}$} & \multirow[t]{2}{*}{$\chi^{2}$-test } & \multirow[t]{2}{*}{$\mathbf{N}$} & \multirow[t]{2}{*}{$\begin{array}{l}\text { Mean } \% \\
\text { Caught }( \pm \text { sem })^{1}\end{array}$} \\
\hline & & 0 & I & & & \\
\hline yeast $\mathrm{CO}_{2}(17.5 \mathrm{~g})$ & no odour & $\underline{367}$ & 101 & $P<0.001$ & 800 & $58.5 \pm 5.7$ \\
\hline yeast $\mathrm{CO}_{2}(17.5 \mathrm{~g})$ & human & 115 & $\underline{267}$ & $P<0.001$ & 800 & $47.8 \pm 6.2$ \\
\hline ind. $\mathrm{CO}_{2}(100 \mathrm{ml} / \mathrm{min})$ & human & 169 & $\underline{259}$ & $P<0.001$ & 800 & $53.5 \pm 5.5$ \\
\hline yeast $\mathrm{CO}_{2}(17.5 \mathrm{~g})+$ worn sock & human & $\underline{454}$ & 96 & $P<0.001$ & 800 & $68.8 \pm 9.3$ \\
\hline ind. $\mathrm{CO}_{2}(100 \mathrm{ml} / \mathrm{min})+$ worn sock & human & 407 & 184 & $P<0.001$ & 800 & $73.9 \pm 7.5$ \\
\hline
\end{tabular}

Yeast $=$ yeast-produced $\left(17.5 \mathrm{~g}\right.$ yeast $+250 \mathrm{~g}$ sugar $+2 \frac{1}{2} \mathrm{~L}$ water $)$.

Ind. = industrial $(100 \mathrm{ml} / \mathrm{min})$.

$\mathrm{O}=$ number of mosquitoes caught in the MM-X trap outside the house.

$\mathrm{I}=$ total number of mosquitoes caught in 2 CDC light traps and found resting inside the house.

$\mathrm{N}=$ total number of mosquitoes released.

${ }^{1}$ Mean percentage caught expressed as the number of female mosquitoes recovered from inside the three traps (1 MM-X, 2 CDC) and the house together divided by the number of mosquitoes that flew out of the release cage.

Underlined number: significant higher catch $\left(\chi^{2}\right.$-test, $\left.\mathrm{P}<0.05\right)$. 


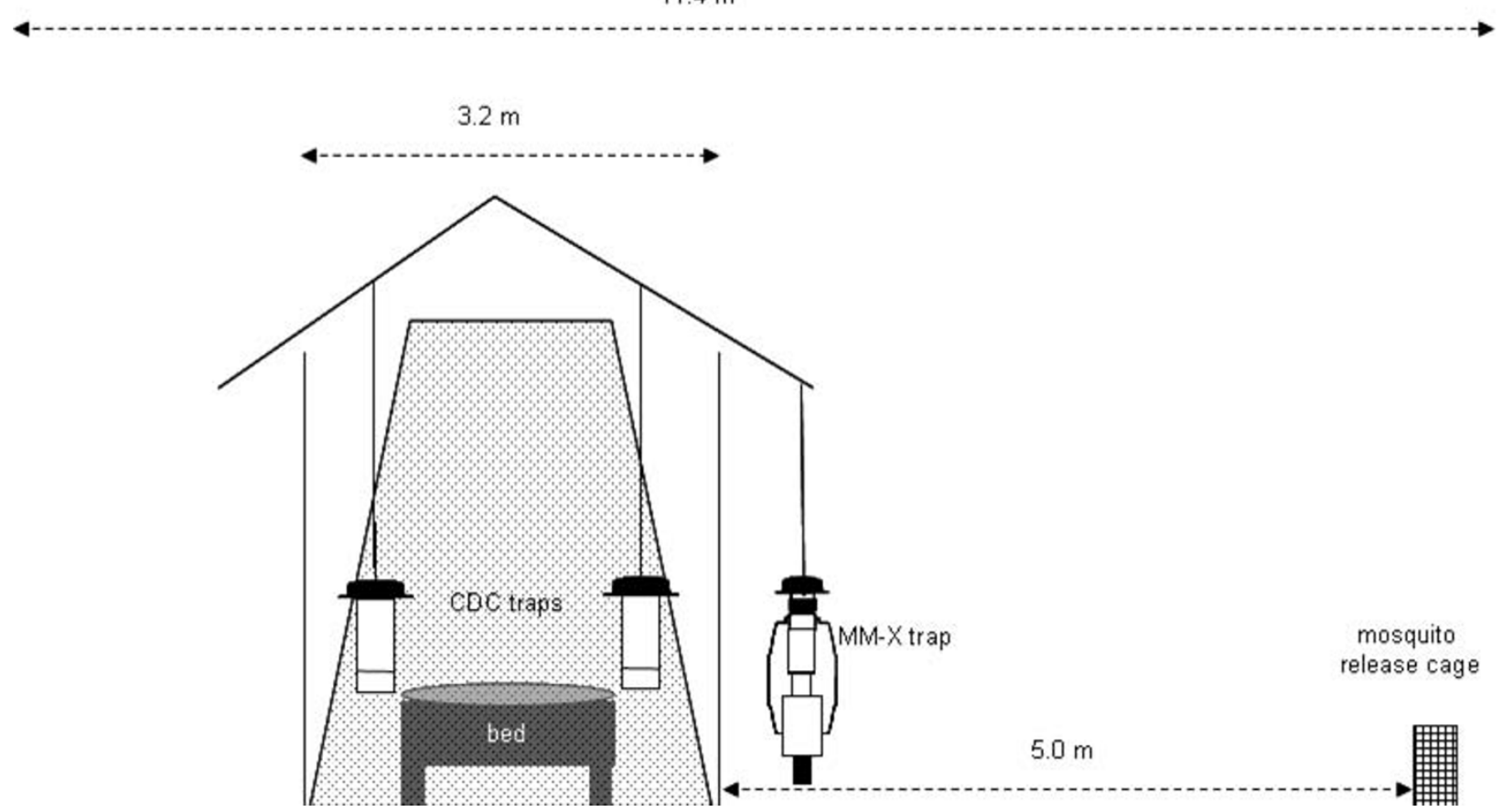

Figure 2 Diagram showing the placement of the three traps inside (two CDC traps) and outside (a MM-X trap) an African house during the experiments conducted in the MalariaSphere [24].

and $2 \frac{1}{2} \mathrm{~L}$ of tap water in each $5 \mathrm{~L}$ bottle. In the second series the effect of the combination of $\mathrm{CO}_{2}$ and human emanations on the trap catches was examined by testing industrial $\mathrm{CO}_{2}$ at a flow rate of $250 \mathrm{ml} / \mathrm{min}$ with or without the addition of a worn sock, and yeast-generated $\mathrm{CO}_{2}$ produced by $35 \mathrm{~g}$ of dry yeast (Angel), $250 \mathrm{~g}$ sugar (Sony) and $2 \frac{1}{2} \mathrm{~L}$ of tap water in each $5 \mathrm{~L}$ bottle with or without the addition of a worn sock. Each experiment ran from 8:30 pm until 6:30 am, after which the mosquitoes in the traps were killed by placing the traps in a freezer and counted. Surgical gloves were worn to avoid contamination of equipment with human volatiles.

The mosquitoes caught in each trap during one night were morphologically identified and counted. Culicines were identified to genus, anophelines to species. Female An. gambiae sensu lato mosquitoes were placed in a 2 $\mathrm{ml}$ Eppendorf tube with dry silica gel and a piece of cotton wool. These mosquitoes were transported to the Laboratory of Entomology of Wageningen University for species identification. The Bender buffer method [39] was used to extract DNA from a mosquito leg and part of the abdomen of each mosquito, followed by polymerase chain reaction (PCR) analysis [40].

\section{Yeast-produced $\mathrm{CO}_{2}$ concentration measurements}

The concentration of yeast-generated $\mathrm{CO}_{2}$ produced by $17.5 \mathrm{~g}$ of dry yeast, $250 \mathrm{~g}$ sugar and $2 \frac{1}{2} \mathrm{~L}$ of tap water in each $5 \mathrm{~L}$ bottle and flowing from a MM-X trap was measured in the laboratory using a Xentra $4100 \mathrm{CO}_{2}$ analyser (Servomex, The Netherlands). The data were transferred to a PC using Das Wizard 2.0 software (Measuring Computing Corporation, USA). The analyser measured at $1 \mathrm{~Hz}$ and was programmed to shift to the next measuring point after 60 successive readings. The average of these 60 readings was plotted in a graph. The analyzer measured over a range of 0-1030 ppm with an accuracy of $0.1 \mathrm{ppm}$.

Three series of readings, each for a duration of $20 \mathrm{~min}$, were taken at different times after mixing the yeast-sugar solution $\left(1 \frac{1}{2}, 25^{1 / 2}\right.$ and $\left.49^{1 / 2} \mathrm{~h}\right)$. For each series of readings, three measuring points were positioned at different distances from the MM-X trap (Table 2). To make a comparison with concentrations flowing from a MM-X trap baited with industrial $\mathrm{CO}_{2}$ another three series of readings, at different distances from the MM-X trap, were made (Table 2). For this comparison the human equivalent of $\mathrm{CO}_{2}$ percentage present in breath $(5 \%)$ and the amount released $(250 \mathrm{ml} / \mathrm{min})$ were chosen $[1,2]$.

\section{Statistical analysis}

For each dual-choice test (laboratory and semi-field experiments) a $\chi^{2}$-test was used to test whether the distribution of the total number of mosquitoes caught in the treatment or control trap over all replicates differed from a $1: 1$ distribution. A $\chi^{2}$-test was also used to 
compare the total number of mosquitoes found inside (total number caught by the two CDC light traps + found resting inside the house) and caught outside (by the MM-X trap) the house in the MalariaSphere. Effects were considered to be significant when $\mathrm{P}<0.05$.

Of the mosquitoes caught during the field experiments, the rarely caught male mosquitoes were discarded from the data. Due to many zeros, the numbers of anopheline and Aedes females were transformed (natural logarithm of $(x+1))$ before subjection to a Generalized Linear Model (GLM; Genstat ${ }^{\circ}$ release 12.1; Normal distribution, fitted terms: night, house, treatment, and when significant the interaction between house and treatment). Mansonia, Culex and total counts were not transformed before subjection to a GLM (Poisson distribution, linked in log, dispersion estimated to account for heterogeneity, fitted terms: night, house, treatment, and when significant the interaction between house and treatment). Two-sided t-probabilities were calculated to test pairwise differences of means. Effects were considered to be significant when $\mathrm{P}<0.05$.

\section{Results}

\section{Laboratory experiments}

Experiments with two unbaited MM-X traps revealed no positional effect within the cage $(P=0.24, \mathrm{n}=297$; Table 3). In total, $15.5 \%$ of the mosquitoes were caught by the two traps. A trap baited with a worn sock caught significantly more mosquitoes than a trap baited with a clean sock $(\mathrm{P}<0.001, \mathrm{n}=277)$. The two traps together caught on average $41.6 \%$ of the mosquitoes that flew out of the release cage.

A trap baited with yeast-produced $\mathrm{CO}_{2}$, produced by a mixture of $7 \mathrm{~g}$ of dry yeast, $100 \mathrm{~g}$ sugar and $1 \mathrm{~L}$ of tap water in each $1.5 \mathrm{~L}$ bottle, caught significantly more mosquitoes than an unbaited trap $(\mathrm{P}<0.001, \mathrm{n}=279)$. During these experiments, on average $77.0 \%$ of the mosquitoes released were caught. Also when the other trap was baited with industrial $\mathrm{CO}_{2}(15 \mathrm{ml} / \mathrm{min})$ led through two $1.5 \mathrm{~L}$ bottles each filled with $1 \mathrm{~L}$ of sugar water, the trap baited with yeast-produced $\mathrm{CO}_{2}$ (two $1.5 \mathrm{~L}$ bottles with each $7 \mathrm{~g}$ dry yeast $+100 \mathrm{~g}$ sugar $+1 \mathrm{~L}$ water) caught significantly more mosquitoes $(\mathrm{P}<0.001, \mathrm{n}=$ 298 , in total $51.6 \%$ caught).

Significantly more mosquitoes were caught by traps baited with yeast-produced $\mathrm{CO}_{2}$ combined with a worn sock than traps baited with a worn sock only. This was observed when two $1.5 \mathrm{~L}$ bottles each containing $7 \mathrm{~g}$ dry yeast $+100 \mathrm{~g}$ sugar $+1 \mathrm{~L}$ water were used for the production of yeast-produced $\mathrm{CO}_{2}$ and when one $25 \mathrm{~L}$ container with $70 \mathrm{~g}$ of dry yeast, $1 \mathrm{~kg}$ of sugar and $10 \mathrm{~L}$ of tap water was used $(\mathrm{P}=0.007, \mathrm{n}=278$ respectively $\mathrm{P}<$ $0.001, \mathrm{n}=371)$. In total a mean of $55.5 \%$ and $78.8 \%$, respectively, of the mosquitoes that had left the release cage were caught during these experiments.

\section{Semi-field experiments \\ Effect of $\mathrm{CO}_{2}$ flow rate on trap catches}

No positional effects were found in the cage when both traps were left unbaited $(\mathrm{P}=0.33, \mathrm{n}=200$; Table 4$)$; the two unbaited traps together caught on average $19.0 \%$ of the mosquitoes released. A trap baited with $25 \mathrm{ml} / \mathrm{min}$ of industrial $\mathrm{CO}_{2}$ caught similar numbers of mosquitoes as an unbaited trap $(\mathrm{P}=0.07, \mathrm{n}=400)$. In total, a mean of $37.5 \%$ of the mosquitoes was trapped. Traps baited with industrial $\mathrm{CO}_{2}$ at a flow rate of $60,100,250$ or 500 $\mathrm{ml} / \mathrm{min}$ caught significantly more mosquitoes than unbaited traps $(\mathrm{P}<0.001,<0.001,<0.001$ and 0.03 , respectively, $\mathrm{n}=400)$. The traps caught on average 30.5 , $54.8,39.5$, and $29.5 \%$ of the females that left the release cage, respectively.

\section{Effect of yeast-produced $\mathrm{CO}_{2}$ on trap catches}

Experiments in the screen house with unbaited traps revealed no bias for either side $(\mathrm{P}=0.64, \mathrm{n}=800$; Table 5). The two unbaited traps together caught only $5.1 \%$ of the mosquitoes that were released. A worn sock attracted significantly more mosquitoes than a clean sock $(P<0.001, n=800)$; on average $43.1 \%$ of the mosquitoes were trapped.

Significantly more mosquitoes were caught by traps baited with yeast-produced $\mathrm{CO}_{2}$ than unbaited traps, independent of the ratio used for the yeast-sugar solution $(\mathrm{P}<0.001, \mathrm{n}=800)$. Traps baited with yeast-produced $\mathrm{CO}_{2}$ also caught significantly more mosquitoes when tested against traps baited with industrial $\mathrm{CO}_{2}$, independent of the flow rate tested $(\mathrm{P}<0.001, \mathrm{n}=800)$. On average, between 32.8 and $71.3 \%$ of the females were caught (Table 5).

As expected, traps baited with the combination of yeast-produced $\mathrm{CO}_{2}$ (17.5 g of dry yeast (Angel), $250 \mathrm{~g}$ sugar (Sony) and $2^{1 / 2} \mathrm{~L}$ of tap water in each $5 \mathrm{~L}$ bottle) and a worn sock caught significantly more mosquitoes than unbaited traps $(\mathrm{P}<0.001, \mathrm{n}=800)$, catching in total $53.0 \%$ of the released mosquitoes (Table 5). This combination attracted also significantly more mosquitoes than a worn sock alone $(\mathrm{P}<0.001, \mathrm{n}=800)$, resulting in a total trapping efficacy of $79.5 \%$. Significantly fewer mosquitoes were caught by traps baited with a combination of industrial $\mathrm{CO}_{2}(100 \mathrm{ml} / \mathrm{min})$ and a worn sock than traps baited with yeast-produced $\mathrm{CO}_{2}$ and a worn sock $(\mathrm{P}=0.002, \mathrm{n}=800$, in total $75.9 \%)$.

Twenty-four hours after mixing the ingredients, significantly more mosquitoes were trapped using yeast-produced $\mathrm{CO}_{2}$ than when no bait was used $(\mathrm{P}<0.001, \mathrm{n}=$ 800 ), catching a mean total of $18.8 \%$ (Table 5 ). However, significantly more mosquitoes were caught by traps 
baited with industrial $\mathrm{CO}_{2}(100 \mathrm{ml} / \mathrm{min})$ than by traps baited with yeast-produced $\mathrm{CO}_{2}$ prepared $24 \mathrm{~h}$ before the start of the dual-choice trapping experiments $(\mathrm{P}<$ $0.001, \mathrm{n}=800 ; 78.0 \%)$. After $48 \mathrm{~h}$, traps baited with yeast-produced $\mathrm{CO}_{2}$ caught similar numbers of mosquitoes as unbaited traps $(\mathrm{P}=0.11, \mathrm{n}=800,12.3 \%)$, and significantly fewer mosquitoes than traps baited with industrial $\mathrm{CO}_{2}(\mathrm{P}<0.001, \mathrm{n}=800,46.5 \%)$.

\section{Effect of $\mathrm{CO}_{2}$-baited traps on house entry behaviour}

The number of mosquitoes trapped by a MM-X trap baited with yeast-produced $\mathrm{CO}_{2}$ hanging outside the house in the MalariaSphere was significantly higher than the total number of mosquitoes that entered the house when unoccupied (total number caught by the two CDC light traps + found resting inside the house) $(\mathrm{P}<0.001$, $\mathrm{n}=800$; Table 6 ). In total, $58.5 \%$ of the mosquitoes that were released were either caught by the three traps (one MM-X, two CDC light traps) or found resting inside the house. In contrast, when the house was occupied by a human sleeping under a bed net, significantly more mosquitoes entered the house than were caught by the yeast-produced $\mathrm{CO}_{2}$-baited MM-X trap $(\mathrm{P}<0.001, \mathrm{n}=$ 800). This was also the case when the MM-X trap was baited with industrial $\mathrm{CO}_{2}(100 \mathrm{ml} / \mathrm{min} ; \mathrm{P}<0.001, \mathrm{n}=$ 800 ). Together, $47.8 \%$ (yeast-produced), respectively $53.5 \%$ (industrial) of the mosquitoes were retrieved, 'outdoors' plus 'indoors'.

When a worn sock was added to the MM-X trap baited with either yeast-produced or industrial $\mathrm{CO}_{2}$, significantly more mosquitoes were trapped outdoors than caught in the CDC traps and found resting indoors where a human was present $(\mathrm{P}<0.001, \mathrm{n}=800)$ : of all mosquitoes trapped, $68.9 \%$ (with industrial $\mathrm{CO}_{2}$ ) to $82.5 \%$ (with yeast-produced $\mathrm{CO}_{2}$ ) were caught in the $\mathrm{CO}_{2}+$ human odour baited MM-X trap. In total, $68.8 \%$ (yeast-produced), respectively $73.9 \%$ (industrial) of the mosquitoes released were recovered from inside the three traps and the house together.

\section{Field experiments}

In the first series of field experiments 392 and in the second series 486 female mosquitoes were caught over eight nights in traps hanging next to the four selected houses. The majority consisted of Mansonia spp. mosquitoes: $48.7 \%$ and $66.0 \%$ in series 1 and 2, respectively. Also Culex spp. females were caught in high proportions: $34.7 \%$ respectively $23.3 \%$ of the total number of female mosquitoes found in the traps. Of the anophelines (12.2\% and 9.7\%, respectively) 3.8\% respectively $5.1 \%$ were An. gambiae s.l. females. PCR tests revealed that all (except five specimens that could not be identified) of the An. gambiae s.l. specimens were Anopheles arabiensis. The majority of the anophelines were Anopheles coustani females; only a few Anopheles funestus
(1\%) were found in the traps. In addition, $4.3 \%$ respectively $1.0 \%$ of the mosquitoes caught were Aedes spp.

GLM analysis showed that both in series 1 and 2 the average number of mosquitoes caught by the four traps hardly varied during the eight nights, whereas the location of the trap (i.e. house) often significantly affected the number of mosquitoes trapped during a night (Table 7). In the first series a significant effect of treatment was found for Culex and Mansiona spp., as well as for Culex spp. in the second series.

In the case of An. gambiae s.l., the effect of the different baits (treatment) on the number of mosquitoes caught depended on the location of the trap $\left(\mathrm{P}_{\text {interaction }}\right.$ $=0.04$ in series 1 and $P_{\text {interaction }}=0.03$ in series 2 ). In the first series, traps baited with industrial $\mathrm{CO}_{2}$ caught significantly more An. gambiae s.l. than unbaited traps $(\mathrm{P}=0.02)$, but similar numbers as traps baited with yeast-produced $\mathrm{CO}_{2}(\mathrm{P}=0.14$ and 0.33 , respectively; Table 7). The second series of experiments showed that, overall, adding a worn sock to either yeast-produced or industrial $\mathrm{CO}_{2}$ significantly increased the number of mosquitoes caught ( $\mathrm{P}=0.003$ and 0.002 , respectively). Traps baited with yeast-produced $\mathrm{CO}_{2}$ plus a worn sock also caught more mosquitoes than industrial $\mathrm{CO}_{2}$ alone $(\mathrm{P}=0.02)$. The majority of the An. gambiae s.l. females were trapped next to house \#1 $(\mathrm{P}<0.05)$.

Taking all mosquito species caught during the first series together, unbaited traps caught significantly fewer mosquitoes than odour-baited traps $(\mathrm{P}<0.05)$. Traps baited with yeast-produced $\mathrm{CO}_{2}$ at the lowest flow rate caught significantly fewer mosquitoes than traps baited with yeast-produced $\mathrm{CO}_{2}$ at the highest flow rate and traps baited with industrial $\mathrm{CO}_{2}(\mathrm{P}=0.009$ and 0.003 , respectively). Traps baited with the latter two baits caught similar numbers of mosquitoes $(P=0.74)$. In the second series the location of the traps determined the total numbers of mosquitoes caught $(P=0.003)$, independent of treatment.

\section{Yeast-produced $\mathrm{CO}_{2}$ concentration measurements}

The carbon dioxide concentrations measured at different distances from a MM-X trap are summarized in Figure 3. It shows clearly the distance effect on the concentration of $\mathrm{CO}_{2}$, the further away from the MM-X trap the lower the $\mathrm{CO}_{2}$ concentration, independent of its source $\left(\mathrm{CO}_{2}\right.$ cylinder or yeast-sugar solution $1 \frac{1}{2}, 25 \frac{1}{2}$ or $49^{1 / 2} \mathrm{~h}$ post mixing). Concentrations measured at a distance of 200 $\mathrm{cm}$ or at a height of $100 \mathrm{~cm}$ were between 400 and 500 $\mathrm{ppm}$. Measurements taken $1 \frac{1}{2}$ hours after mixing the yeast-sugar solution, within or close to the trap ( 0 and 30 $\mathrm{cm}$ from the trap, $5 \mathrm{~cm}$ above ground level) also showed $\mathrm{CO}_{2}$ levels between 400 and $500 \mathrm{ppm}$.

Carbon dioxide concentrations produced by yeastsugar solutions $25^{1 / 2}$ or $49 \frac{1}{2}$ h post mixing, measured 
Table 7 Mean \pm SD mosquitoes caught during field experiments by MM-X traps baited with different test odours

\begin{tabular}{|c|c|c|c|c|c|c|c|c|c|c|}
\hline Series & Test odour & An. coustani & An. funestus & An. gambiae s.l. & tot. anoph. & Aedes spp. & Culex spp. & Mansonia spp. & tot. non-anoph. & tot. mosquitoes \\
\hline \multirow[t]{4}{*}{1} & no odour & $0 \pm 0 \mathrm{a}$ & $0 \pm 0 \mathrm{a}$ & $0 \pm 0 \mathrm{a}$ & $0 \pm 0 \mathrm{a}$ & $0.4 \pm 0.5 \mathrm{a}$ & $1.3 \pm 1.5 \mathrm{a}$ & $0.5 \pm 0.8 \mathrm{a}$ & $2.1 \pm 1.8 \mathrm{a}$ & $2.1 \pm 1.8 \mathrm{a}$ \\
\hline & ind. $\mathrm{CO}_{2}(250 \mathrm{ml} / \mathrm{min})$ & $1.3 \pm 2.8 \mathrm{ab}$ & $0.1 \pm 0.4 \mathrm{a}$ & $1.0 \pm 2.1 \mathrm{~b}$ & $2.4 \pm 4.8 \mathrm{ab}$ & $0.6 \pm 0.7 a$ & $7.9 \pm 6.9 \mathrm{ab}$ & $10.3 \pm 7.5 \mathrm{c}$ & $18.8 \pm 12.6 \mathrm{C}$ & $21.1 \pm 17.1 \mathrm{C}$ \\
\hline & yeast $\mathrm{CO}_{2}(17.5 \mathrm{~g})$ & $0.6 \pm 0.7 \mathrm{ab}$ & $0.1 \pm 0.4 \mathrm{a}$ & $0.4 \pm 1.1 \mathrm{ab}$ & $1.1 \pm 1.6 \mathrm{ab}$ & $0.1 \pm 0.4 \mathrm{a}$ & $2.3 \pm 2.1 \mathrm{a}$ & $4.9 \pm 6.5 b$ & $7.3 \pm 6.3 b$ & $8.4 \pm 6.9 b$ \\
\hline & yeast $\mathrm{CO}_{2}(35 \mathrm{~g})$ & $1.6 \pm 1.9 b$ & $0.4 \pm 1.1 \mathrm{a}$ & $0.5 \pm 1.1 \mathrm{ab}$ & $2.5 \pm 2.9 \mathrm{~b}$ & $0.5 \pm 1.4 \mathrm{a}$ & $5.6 \pm 6.7 b$ & $8.3 \pm 7.9 b c$ & $14.9 \pm 14.6 \mathrm{C}$ & $17.4 \pm 14.0 \mathrm{C}$ \\
\hline$P_{\text {night }}$ & & 0.80 & 0.17 & 0.16 & 0.76 & 0.29 & 0.43 & 0.17 & 0.15 & 0.26 \\
\hline Phouse & & 0.17 & 0.69 & $0.01^{*}$ & 0.04 & 0.87 & 0.11 & 0.02 & 0.01 & 0.002 \\
\hline$P_{\text {treatm }}$ & & 0.14 & 0.69 & $0.12^{*}$ & 0.07 & 0.28 & 0.007 & $<0.001$ & $<0.001$ & $<0.001$ \\
\hline \multirow[t]{4}{*}{2} & ind. $\mathrm{CO}_{2}(250 \mathrm{ml} / \mathrm{min})$ & $0.6 \pm 1.1 \mathrm{ab}$ & $0 \pm 0 \mathrm{a}$ & $0 \pm 0 \mathrm{a}$ & $0.6 \pm 1.6 \mathrm{a}$ & $0.3 \pm 0.5 a$ & $4.4 \pm 3.9 b$ & $7.3 \pm 5.2 \mathrm{a}$ & $11.9 \pm 8.1 \mathrm{ab}$ & $12.5 \pm 8.9 \mathrm{ab}$ \\
\hline & ind. $\mathrm{CO}_{2(250 \mathrm{~m} / \mathrm{min})}+$ worn sock & $0.8 \pm 0.7 b$ & $0.3 \pm 0.5 a$ & $1.3 \pm 1.8 \mathrm{~b}$ & $2.3 \pm 2.7 b$ & $0.3 \pm 0.5 a$ & $5.4 \pm 6.0 \mathrm{~b}$ & $12.9 \pm 7.8 \mathrm{a}$ & $18.5 \pm 10.1 \mathrm{~b}$ & $20.8 \pm 11.9 \mathrm{~b}$ \\
\hline & yeast $\mathrm{CO}_{2}(35 \mathrm{~g})$ & $0.8 \pm 1.0 \mathrm{~b}$ & $0.1 \pm 0.4 \mathrm{a}$ & $0.4 \pm 1.1 \mathrm{a}$ & $1.3 \pm 2.1 \mathrm{ab}$ & $0.1 \pm 0.4 \mathrm{a}$ & $2.8 \pm 4.4 \mathrm{a}$ & $8.1 \pm 6.5 \mathrm{a}$ & $11.0 \pm 7.8 \mathrm{a}$ & $12.3 \pm 9.2 \mathrm{a}$ \\
\hline & yeast $\mathrm{CO}_{2(35 \mathrm{~g})}+$ worn sock & $0 \pm 0 \mathrm{a}$ & $0.3 \pm 0.7 \mathrm{a}$ & $1.5 \pm 1.6 b$ & $1.8 \pm 2.3 \mathrm{ab}$ & $0 \pm 0 \mathrm{a}$ & $1.6 \pm 1.7 \mathrm{a}$ & $11.9 \pm 8.6 \mathrm{a}$ & $13.5 \pm 8.1 \mathrm{ab}$ & $15.3 \pm 9.9 \mathrm{ab}$ \\
\hline$P_{\text {night }}$ & & 0.22 & 0.47 & 0.32 & 0.83 & 0.89 & 0.001 & 0.29 & 0.39 & 0.44 \\
\hline$P_{\text {house }}$ & & 0.02 & 0.004 & $<0.001^{*}$ & 0.001 & 0.58 & $<0.001$ & 0.008 & 0.004 & 0.003 \\
\hline$P_{\text {treatm }}$ & & 0.05 & 0.46 & $0.001^{*}$ & 0.18 & 0.58 & 0.003 & 0.15 & 0.17 & 0.16 \\
\hline
\end{tabular}

Yeast $=$ yeast-produced $\left(17.5 \mathrm{~g}\right.$ yeast $+250 \mathrm{~g}$ sugar $+2 \frac{1}{2} \mathrm{~L}$ water or $35 \mathrm{~g}$ yeast $+500 \mathrm{~g}$ sugar $\left.+2^{1 / 2} \mathrm{~L}\right)$

Ind. $=$ industrial $(250 \mathrm{ml} / \mathrm{min})$

tot. $=$ total

anoph. $=$ anophelines

Mean numbers caught marked with different letters within a column within same series are significantly different (GLM, $\mathrm{P}<0.05)$

* interaction between house and treatment (GLM, $P=0.04$ in series 1 and $P=0.03$ in series 2$)$ 


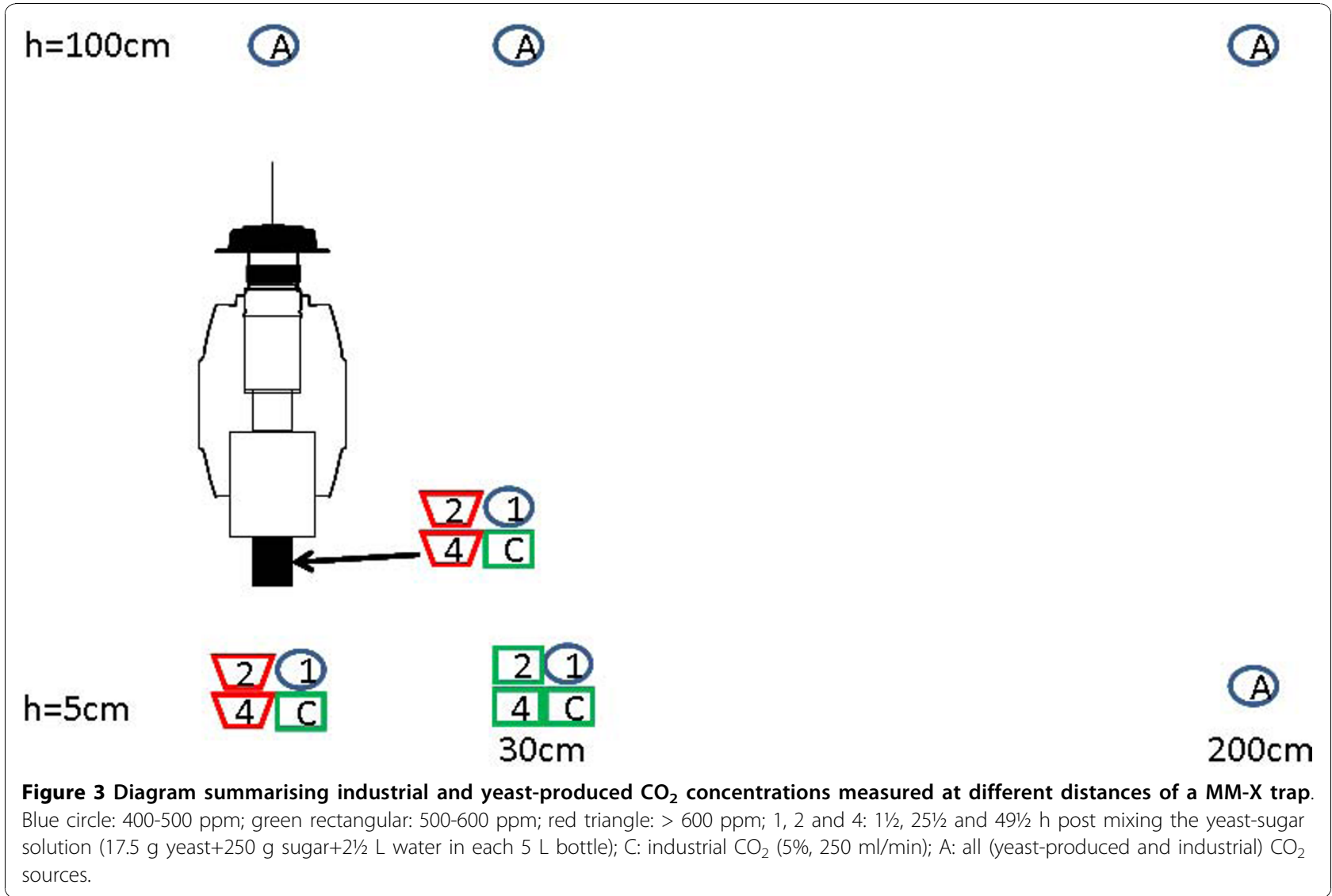

inside or $10 \mathrm{~cm}$ below the trap outlet, was higher (600$850 \mathrm{ppm})$ than when industrial $\mathrm{CO}_{2}(5 \%, 250 \mathrm{ml} / \mathrm{min})$ was used to bait the trap (500-600 ppm). At $30 \mathrm{~cm}$ from the trap and $5 \mathrm{~cm}$ above ground level, $\mathrm{CO}_{2}$ levels were similar for industrial and yeast-sugar solutions $251 / 2$ and $49 \frac{1}{2} \mathrm{~h}$ after mixing (450-550 ppm).

\section{Discussion}

Based on the results, $\mathrm{CO}_{2}$, and possibly other volatiles, produced by fermenting baker's yeast appears a promising alternative for industrial $\mathrm{CO}_{2}$ supplied from expensive and cumbersome cylinders to lure An. gambiae females towards traps. Trap catches were similar or even significantly higher when yeast-produced $\mathrm{CO}_{2}$ was used to bait MM-X traps compared to industrial $\mathrm{CO}_{2}$. This finding presents an important step in the development of a cheap and easily applicable $\mathrm{CO}_{2}$ source that could be used for mosquito surveillance or removal in rural settings.

The indoor and semi-field trapping experiments showed that yeast-produced $\mathrm{CO}_{2}$, produced by yeastsugar solutions in different ratios, significantly increased the number of An. gambiae females caught by MM-X traps. Traps baited with yeast-produced $\mathrm{CO}_{2}$ also caught significantly more mosquitoes than traps baited with industrial $\mathrm{CO}_{2}$ at a similar or probably higher flow rate. Yeast-produced $\mathrm{CO}_{2}$ also significantly increased the catches of traps baited with human odour collected on nylon socks (Tables 3 and 5). These finding are in agreement with previous research with industrial $\mathrm{CO}_{2}$, showing the importance of this compound in the trapping of this mosquito species [5,11-13].

The experiments conducted in the MalariaSphere revealed that a trap baited with yeast-produced $\mathrm{CO}_{2}$ hanging outdoors next to a house caught significantly more An. gambiae than entered the unoccupied house. This was not the case when a human was sleeping inside the house, regardless of the use of yeast-produced or industrial $\mathrm{CO}_{2}$ as only bait in a trap placed outdoors. However, when adding human foot volatiles to either yeast-produced or industrial $\mathrm{CO}_{2}$, significantly fewer mosquitoes were found inside the occupied house than in the MM-X trap placed under the eaves outdoors (Table 6), proving that the combination of human skin odour $+\mathrm{CO}_{2}$ effectively prevented a large proportion of mosquitoes entering the house. These encouraging results suggest that it is possible to develop traps that can be placed outdoors, baited with $\mathrm{CO}_{2}$ and a synthetic blend mimicking human odour, to reduce the number of malaria mosquitoes entering houses through the 
eaves. Jawara et al [13], however, showed that in The Gambia human odour-baited traps placed either next to or inside an experimental house did not decrease the number of wild mosquitoes entering the house. Other measures, like house screening or application of repellent odours, to prevent house entry may therefore be necessary to apply in addition to odour-baited traps [41]. Semi-field and field experiments are ongoing to explore this further.

During the field experiments in the present study, mosquito numbers were low and no An. gambiae s.s., the subject of our study, was caught. Its sibling species, An. arabiensis, however, was present and collected significantly more with human skin odour $+\mathrm{CO}_{2}$ than with $\mathrm{CO}_{2}$ alone (Table 7). Similar comparative results for An. gambiae s.s. and An. arabiensis with odour baits were also reported by Okumu et al [42], suggesting that both important malaria vectors can be collected with odour-baited traps. Also, yeast-produced $\mathrm{CO}_{2}$ seems to be as good as industrial $\mathrm{CO}_{2}$ as bait for several other vector and nuisance mosquito species (Table 7).

In the laboratory and screen house significantly more mosquitoes were caught in traps baited with yeast-produced $\mathrm{CO}_{2}$ than in traps baited with industrial $\mathrm{CO}_{2}$ when tested directly against each other. Since the flow rates were either comparable or more likely lower for yeast-produced $\mathrm{CO}_{2}$ (e.g., due to lower temperatures during the night), possible differences in flow rates between industrial and yeast-produced $\mathrm{CO}_{2}$ did not result in differences in attractiveness. It is, however, known that growing yeast produces additional compounds besides $\mathrm{CO}_{2}$ [20]. Preliminary analyses of headspaces of yeast-sugar solutions $(70 \mathrm{~g} \mathrm{Y}+1000 \mathrm{~g} \mathrm{~S}+10$ $\mathrm{L} \mathrm{W}$ in $25 \mathrm{~L}$ container), two and $28 \mathrm{~h}$ post mixing, revealed that yeast produces volatile organic compounds (VOCs) previously found in human emanations and which may therefore play a role in the host-seeking behaviour of An. gambiae s.s. [43-46] (Table 8). These additional VOCs may explain the differences found in catches between traps baited with yeast-produced $\mathrm{CO}_{2}$ compared to traps baited with industrial $\mathrm{CO}_{2}$ and should be further examined.

Measurements of $\mathrm{CO}_{2}$ concentrations at different distances from a MM-X trap showed that, at close range of the trap, $\mathrm{CO}_{2}$ concentrations produced by yeast-sugar solutions were higher than from cylinders containing 5\% $\mathrm{CO}_{2}$ (equal to the concentration in human breath). Further away from the trap, at $30 \mathrm{~cm}$, concentrations of industrial and yeast-produced $\mathrm{CO}_{2}$ had dropped to a comparable low level (Figure 3). Even though this was measured in a laboratory where no wind was present, it is very likely that also in the field packets of $\mathrm{CO}_{2}$ are produced by yeast-sugar solutions with concentrations similar to or higher than what is produced by humans
Table 8 Preliminary data of volatile organic compounds found to be more present in headspace samples of yeast-sugar solutions ( 2 or $28 \mathrm{~h}$ post mixing) than in background samples (order of compounds based on retention time on a DB-5 column)

\begin{tabular}{|c|c|c|}
\hline Compound & $\begin{array}{l}\text { Yeast } \\
\text { sample }\end{array}$ & $\begin{array}{l}\text { Human emanation } \\
\text { references }\end{array}$ \\
\hline ethanol & $2 \mathrm{~h}, 28 \mathrm{~h}$ & {$[54-56]$} \\
\hline 2-methylpropanal & $2 \mathrm{~h}$ & {$[57]$} \\
\hline ethyl acetate & $2 \mathrm{~h}, 28 \mathrm{~h}$ & {$[56]$} \\
\hline 2-methyl-1-propanol & $2 \mathrm{~h}, 28 \mathrm{~h}$ & {$[54]$} \\
\hline 3-methylbutanal & $28 \mathrm{~h}$ & {$[46,58,59]$} \\
\hline 1-pentanol & $28 \mathrm{~h}$ & {$[55]$} \\
\hline 3-hydroxy-2-butanone & $2 \mathrm{~h}$ & {$[46,55]$} \\
\hline 3-methyl-1-butanol & $2 \mathrm{~h}, 28 \mathrm{~h}$ & {$[46,55]$} \\
\hline 2-methylpropanoic acid & $2 \mathrm{~h}, 28 \mathrm{~h}$ & {$[60,61]$} \\
\hline 3-methylbutanoic acid & $2 \mathrm{~h}$ & {$[46,55,60-62]$} \\
\hline benzeneethanol & $2 h, 28 \mathrm{~h}$ & {$[46,57,62,63]$} \\
\hline $\begin{array}{l}\text { isobutyl ester of ethanoic } \\
\text { acid }\end{array}$ & $28 \mathrm{~h}$ & \\
\hline ethyl 2-methylbutanoate & $28 \mathrm{~h}$ & {$[55]$} \\
\hline ethyl 3-methylbutanoate & $28 \mathrm{~h}$ & {$[55]$} \\
\hline 3-methylbutyl acetate & $28 \mathrm{~h}$ & \\
\hline 2-methylbutyl acetate & $28 \mathrm{~h}$ & \\
\hline ethyl ester of hexanoic acid & $28 \mathrm{~h}$ & \\
\hline 1-dodecene & $28 \mathrm{~h}$ & [63] \\
\hline ethyl ester of octanoic acid & $28 \mathrm{~h}$ & \\
\hline ethyl ester of decanoic acid & $28 \mathrm{~h}$ & \\
\hline $\begin{array}{l}\text { isopentyl ester of octanoic } \\
\text { acid }\end{array}$ & $28 \mathrm{~h}$ & \\
\hline
\end{tabular}

[47-50]. Since mosquitoes respond to small changes in $\mathrm{CO}_{2}$ concentration above ambient, this will be sufficient to induce upwind flight [1,50-52].

In Japan and Malaysia, traps baited with dry ice caught more Culex and Aedes mosquitoes than traps baited with yeast-produced $\mathrm{CO}_{2}[16,53]$. However, the advantages, such as low costs and feasible logistics, of the yeastmethod clearly outweigh the logistic disadvantages and relatively high costs associated with both dry ice and $\mathrm{CO}_{2}$ cylinders. Variable $\mathrm{CO}_{2}$ output may occur when using yeast-sugar solutions, probably depending on the ambient temperature. This issue, however, is not problematic, since the current results show that mosquitoes are attracted to yeast-produced $\mathrm{CO}_{2}$, regardless of the concentrations used. In addition, indications have been found that fluctuating concentrations of $\mathrm{CO}_{2}$ above the ambient level induce upwind orientation of mosquitoes [50,52], although the laboratory and field experiments of the present study indicate that higher concentrations are favourable.

Both laboratory and semi-field experiments showed that yeast-produced $\mathrm{CO}_{2}$ is still 'attractive' $24-34 \mathrm{~h}$ post mixing the ingredients (Tables 3 and 5), although less than industrial $\mathrm{CO}_{2}$ (which is released with a constant 
flow rate and concentration), showing that this bait is at least applicable during one sampling night. In the screen house, yeast-produced $\mathrm{CO}_{2}$ lost its attractiveness somewhere between 34 and $48 \mathrm{~h}$ post-mixing the ingredients (Table 5). Carbon dioxide flow rates dropped from 60 $\mathrm{ml} / \mathrm{min}$ after $30 \mathrm{~h}$ to $0 \mathrm{ml} / \mathrm{min}$ within $51 \mathrm{~h}$. In contrast, the $\mathrm{CO}_{2}$ measurements showed that even after $49 \mathrm{~h}$ $\mathrm{CO}_{2}$ concentrations should be sufficiently high to activate mosquitoes (Figure 3) and simultaneous $\mathrm{CO}_{2}$ output measurements showed a flow rate of $30 \mathrm{ml} / \mathrm{min}$. These differences may have been due to temperature differences or tap water of different sources.

\section{Conclusion}

Carbon dioxide and possibly additional volatiles produced by yeast-sugar solutions are attractive to An. gambiae and, therefore, these solutions can be used as baits for the surveillance or possibly removal of this important malaria vector. The results suggest that $\mathrm{CO}_{2}$ is the most important constituent of these VOCs, because addition of human foot volatiles enhanced attraction of mosquitoes similar as with industrial $\mathrm{CO}_{2}$. As long as $\mathrm{CO}_{2}$ production will be sufficient for at least one night, the smaller the bottle and the cheaper and easier accessible the ingredients, the better for implementation in rural areas. This technology could represent a new solution for sampling An. gambiae and other human-biting mosquito species in remote areas, with low financial and technological demands.

\footnotetext{
Acknowledgements

We would like to thank Frans van Aggelen, André Gidding, Leo Koopman (Wageningen University, Laboratory of Entomology, The Netherlands), David Alila, Elizabeth Masinde and David Owaga (ICIPE, Kenya) for rearing mosquitoes. We thank Hans Beijleveld (Wageningen University, Laboratory of Entomology, The Netherlands) and Francel Verstappen (Wageningen University, Laboratory of Plant Physiology, The Netherlands) for preliminary analyses of headspace volatiles. We are grateful to Erick Ambugo, Jackton Arija, Tom Guda, Phoebe Mbadi, Evelyn Olanga, Mike Okal, (ICIPE, Kenya) and inhabitants of Lwanda village (Kenya) for technical assistance and cooperation. Dr. Woody Foster (The Ohio State University, Department of Entomology, USA) is acknowledged for providing MM-X traps in Kenya. We thank Dr. Joop van Loon (Wageningen University, Laboratory of Entomology, The Netherlands) for constructive comments on an earlier version of this manuscript. Ethical approval for the experiments conducted in Kenya was obtained through the joint Kenyatta National Hospital/University of Nairobi ethical review committee (protocol approval number P102/7/2004 amended in 2008). This study was funded by a grant from the Foundation for the National Institutes of Health $(\mathrm{NIH})$ through the Grand Challenges in Global Health Initiative (GCGH\#121).
}

\section{Author details}

'Laboratory of Entomology, Wageningen University, P.O. Box 8031, 6700 EH, Wageningen, The Netherlands. ${ }^{2}$ International Centre of Insect Physiology and Ecology, P.O. Box 30772 - 00100, GPO, Nairobi, Kenya. ${ }^{3}$ School of Biological Sciences, University of Nairobi, P.O. Box 30197 - 00100 GPO, Nairobi, Kenya.

\section{Authors' contributions}

WHS conceived of the idea to test yeast as a carbon dioxide source to trap malaria mosquitoes. The experimental set-up was developed by WHS, KJR, WRM and RCS. WHS and KJR conducted the behavioural experiments, with the assistance of NOV. JS performed the carbon dioxide concentration measurements. RCS analysed the data and drafted the manuscript. All authors contributed to, read and approved the final manuscript.

\section{Competing interests}

The authors declare that they have no competing interests.

Received: 3 June 2010 Accepted: 25 October 2010

Published: 25 October 2010

\section{References}

1. Gillies MT: The role of carbon dioxide in host-finding by mosquitoes (Diptera: Culicidae): a review. Bull Entomol Res 1980, 70:525-532.

2. Mboera LEG, Takken W: Carbon dioxide chemotropism in mosquitoes (Diptera: Culicidae) and its potential in vector surveillance and management programmes. Rev Med Vet Entomol 1997, 85:355-368.

3. Dekker T, Takken W, Cardé RT: Structure of host-odour plumes influences catch of Anopheles gambiae s.s. and Aedes aegypti in a dual-choice olfactomer. Physiol Entomol 2001, 26:124-134.

4. Dekker T, Geier M, Cardé RT: Carbon dioxide instantly sensitizes female yellow fever mosquitoes to human skin odours. J Exp Biol 2005, 208:2963-2972.

5. Qiu YT, Smallegange RC, ter Braak CJF, Spitzen J, Van Loon JJA, Jawara M, Milligan P, Galimard AM, Van Beek TA, Knols BGJ, Takken W: Attractiveness of MM-X traps baited with human or synthetic odor to mosquitoes (Diptera: Culicidae) in The Gambia. J Med Entomol 2007, 44:970-983.

6. Spitzen J, Smallegange RC, Takken W: Effect of human odours and positioning of $\mathrm{CO} 2$ release point on trap catches of the malaria mosquito Anopheles gambiae sensu stricto in an olfactometer. Physiol Entomol 2008, 33:116-122.

7. Kline DL: Traps and trapping techniques for adult mosquito control. J Am Mosa Control Assoc 2006, 22:490-496.

8. Kline DL: Semiochemicals, traps/targets and mass trapping technology for mosquito management. J Am Mosa Control Assoc 2007, 23:241-251.

9. Qiu YT, Spitzen J, Smallegange RC, Knols BGJ: Monitoring systems for adult insect pests and disease vectors. In Emerging Pests and Vector-borne Diseases in Europe. Edited by: Takken W, Knols BGJ. Wageningen, Wageningen Academic Publishers; 2007:329-354.

10. Dekker T, Takken W: Differential responses of mosquito sibling species Anopheles arabiensis and An. quadriannulatus to carbon dioxide, a man or a calf. Med Vet Entomol 1998, 12:136-140.

11. Costantini C, Gibson G, Sagnon N, Della Torre A, Brady J, Coluzzi M: Mosquito responses to carbon dioxide in a west African Sudan savanna village. Med Vet Entomol 1996, 10:220-227.

12. Schmied W, Takken W, Killeen G, Knols BGJ, Smallegange RC: Evaluation of two counterflow traps for testing behaviour-mediating compounds for the malaria vector Anopheles gambiae s.s. under semi-field conditions in Tanzania. Malar J 2008, 7:230.

13. Jawara M, Smallegange RC, Jeffries D, Nwakanma DC, Awolola TS, Knols BGJ, Takken W, Conway DJ: Optimizing odor-baited trap methods for collecting mosquitoes during the malaria season in The Gambia. PLOS ONE 2009, 4:e8167.

14. White GB: Anopheles gambiae complex and disease transmission in Africa. Trans R Soc Trop Med Hyg 1974, 68:278-299.

15. Kline DL: Evaluation of various models of propane-powered mosquito traps. J Vector Ecol 2002, 27:1-7.

16. Saitoh Y, Hattori J, Chinone S, Nihei N, Tsuda Y, Kurahashi H, Kobayashi M: Yeast-generated $\mathrm{CO} 2$ as a convenient source of carbon dioxide for adult mosquito sampling. J Am Mosq Control Assoc 2004, 20:261-264.

17. Van Dijken JP, Weusthuis RA, Pronk JT: Kinetics of growth and sugar consumption in yeasts. Antonie van Leeuwenhoek 1993, 63:343-352.

18. Barnett JA: A history of research on yeasts 5 : the fermentation pathway. Yeast 2003, 20:509-543

19. Walker G, Dijck P: Physiological and molecular responses of yeasts to the environment. In Yeasts in Food and Beverages. Edited by: Querol A, Fleet GH. Berlin Heidelberg, Springer-Verlag; 2006:111-152.

20. Hazelwood LA, Daran J-M, van Maris AJA, Pronk JT, Dickinson JR: The Ehrlich pathway for fusel alcohol production: a century of research on Saccharomyces cerevisiae metabolism. Appl Environ Microbiol 2008, 74:2259-2266. 
21. Kline DL: Comparison of two American biophysics mosquito traps: the professional and a new counterflow geometry trap. J Am Mosq Control Assoc 1999, 15:276-282.

22. Cooperband MF, Cardé RT: Comparison of plume structures of carbon dioxide emitted from different mosquito traps. Med Vet Entomol 2006, 20:1-10.

23. Cooperband MF, Cardé RT: Orientation of Culex mosquitoes to carbon dioxide-baited traps: flight manoeuvres and trapping efficiency. Med Vet Entomol 2006, 20:11-26.

24. Knols B, Niiru B, Mathenge E, Mukabana W, Beier J, Killeen G: MalariaSphere: A greenhouse-enclosed simulation of a natural Anopheles gambiae (Diptera: Culicidae) ecosystem in western Kenya. Malar J 2002, 1:19.

25. Sudia WD, Chamberlain RW: Battery-operated light trap, an improved model. By W. D. Sudia and R. W. Chamberlain, 1962. J Am Mosq Control Assoc 1988, 4:536-538.

26. De Jong R, Knols BGJ: Selection of biting sites on man by two malaria mosquito species. Cell Mol Life Sciences (CMLS) 1995, 51:80-84.

27. Pates H, Takken W, Stuke K, Curtis CF: Differential behaviour of Anopheles gambiae sensu stricto (Diptera: Culicidae) to human and cow odours in the laboratory. Bull Entomol Res 2001, 91:289-296.

28. Qiu YT, Smallegange RC, Hoppe S, van Loon JJA, Bakker EJ, Takken W: Behavioural and electrophysiological responses of the malaria mosquito Anopheles gambiae Giles sensu stricto (Diptera: Culicidae) to human skin emanations. Med Vet Entomol 2004, 18:429-438.

29. Njiru B, Mukabana W, Takken W, Knols B: Trapping of the malaria vector Anopheles gambiae with odour-baited MM-X traps in semi-field conditions in western Kenya. Malar J 2006, 5:39.

30. Smallegange RC, Takken W: Host-seeking behaviour of mosquitoes: responses to olfactory stimuli in the laboratory. In Olfaction in vector-host interactions. Edited by: Takken W, Knols BGJ. Wageningen, Wageningen Academic Publishers; 2010:143-180.

31. Haddow AJ, Ssenkubuge Y: The mosquito of bwamba county, Uganda. IX. Further studies on the biting behaviour of an outdoor population of the Anopheles gambiae Giles complex. Bull Entomol Res 1973, 62:407-414.

32. Maxwell C, Wakibara J, Tho S, Curtis C: Malaria-infective biting at different hours of the night. Med Vet Entomol 1998, 12:325-327.

33. Killeen $G$, Kihonda J, Lyimo $E$, Oketch $F$, Kotas M, Mathenge $E$, Schellenberg J, Lengeler C, Smith T, Drakeley C: Quantifying behavioural interactions between humans and mosquitoes: Evaluating the protective efficacy of insecticidal nets against malaria transmission in rural Tanzania. BMC Infect Dis 2006, 6:161.

34. Snow WF: Studies of house-entering habits of mosquitoes in The Gambia, West Africa: experiments with prefabricated huts with varied wall apertures. Med Vet Entomol 1987, 1:9-21.

35. Njie M, Dilger E, Lindsay SW, Kirby MJ: Importance of eaves to house entry by anopheline, but not culicine, mosquitoes. J Med Entomol 2009, 46:505-510.

36. Mboera L, Kihonda J, Braks M, Knols B: Short report: Influence of centers for disease control light trap position, relative to a human-baited bed net, on catches of Anopheles gambiae and Culex quinquefasciatus in Tanzania. Am J Trop Med Hyg 1998, 59:595-596.

37. Minakawa N, Mutero C, Githure J, Beier J, Yan G: Spatial distribution and habitat characterization of anopheline mosquito larvae in Western Kenya. Am J Trop Med Hyg 1999, 61:1010-1016.

38. Minakawa N, Seda P, Yan G: Influence of host and larval habitat distribution on the abundance of African malaria vectors in western Kenya. Am J Trop Med Hyg 2002, 67:32-38.

39. Takken W, Geene R, Adam W, Jetten TH, van der Velden JA: Distribution and dynamics of larval populations of Anopheles messeae and A. atroparvus in the delta of the rivers Rhine and Meuse, The Netherlands. Ambio 2002, 31:212-218.

40. Scott JA, Brogdon WG, Collins FH: Identification of single specimens of the Anopheles gambiae complex by the polymerase chain reaction. Am J Trop Med Hyg 1993, 4:520-529.

41. Kirby MJ, Ameh D, Bottomley C, Green C, Jawara M, Milligan PJ, Snell PC, Conway DJ, Lindsay SW: Effect of two different house screening interventions on exposure to malaria vectors and on anaemia in children in The Gambia: a randomised controlled trial. The Lancet 2009, 374:998-1009
42. Okumu FO, Killeen GF, Ogoma S, Biswaro L, Smallegange RC, Mbeyela E, Titus E, Munk C, Ngonyani H, Takken W, Hassan M, Mukabana WR, Moore SJ: Development and field evaluation of a synthetic mosquito lure that is more attractive than humans. PLOS ONE 2010, 5:e8951.

43. Qiu YT: Sensory and behavioural responses of the malaria mosquito Anopheles gambiae to human odours. PhD thesis Wageningen University, Laboratory of Entomology; 2005.

44. Smallegange RC, Qiu YT, van Loon JJA, Takken W: Synergism between ammonia, lactic acid and carboxylic acids as kairomones in the hostseeking behaviour of the malaria mosquito Anopheles gambiae sensu stricto (Diptera: Culicidae). Chem Senses 2005, 30:145-152.

45. Smallegange RC, Qiu YT, Bukovinszkine-Kiss G, Van Loon JJA, Takken W: The effect of aliphatic carboxylic acids on olfaction-based host-seeking of the malaria mosquito Anopheles gambiae sensu stricto. J Chem Ecol 2009, 35:933-943.

46. Verhulst N, Beijleveld H, Knols B, Takken W, Schraa G, Bouwmeester H, Smallegange R: Cultured skin microbiota attracts malaria mosquitoes. Malar J 2009, 8:302.

47. Murlis J, Jones CD: Fine-scale structure of odour plumes in relation to insect orientation to distant pheromone and other attractant sources. Physiol Entomol 1981, 6:71-86

48. Voskamp KE: Electroantennogram responses of tsetse flies (Glossina pallidipes) to host odours in an open field and riverine woodland. Physiol Entomol 1998, 23:176-183.

49. Murlis J, Willis MA, Cardé RT: Spatial and temporal structures of pheromone plumes in fields and forests. Physiol Entomol 2000, 25:211-222.

50. Cardé RT, Willis MA: Navigational strategies used by insects to find distant, wind-borne sources of odor. J Chem Ecol 2008, 34:854-866.

51. Grant AJ, Aghajanian JG, O'Connell RJ, Wigton BE: Electrophysiological responses of receptor neurons in mosquito maxillary palp sensilla to carbon dioxide. J Comp Physiol A: Neuroethology, Sensory, Neural, and Behavioral Physiol 1995, 177:389-396

52. Cardé RT, Gibson G: Host finding by female mosquitoes: Mechanisms of orientation to host odours and other cues. In Olfaction in vector-host interactions. Edited by: Takken W, Knols BGJ. Wageningen, Wageningen Academic Publishers; 2010:115-142.

53. Oli K, Jeffery J, Vythilingam I: A comparative study of adult mosquito trapping using dry ice and yeast generated carbon dioxide. Trop Biomed 2005, 22:249-251.

54. Ellin Rl, Farrand RL, Oberst FW, Crouse CL, Billups NB, Koon WS, Musselman NP, Sidell FR: An apparatus for the detected and quantitation of volatile human effluents. J Chromatogr A 1974, 100:137-152.

55. Meijerink J, Braks MAH, Brack AA, Adam W, Dekker T, Posthumus MA, Van Beek TA, Van Loon JJA: Identification of Olfactory Stimulants for Anopheles gambiae from Human Sweat Samples. J Chem Ecol 2000, 26:1367-1382.

56. Deng C, Zhang $X$, Li N: Investigation of volatile biomarkers in lung cancer blood using solid-phase microextraction and capillary gas chromatography-mass spectrometry. J Chromatogr B 2004, 808:269-277.

57. Bernier UR, Kline DL, Barnard DR, Schreck CE, Yost RA: Analysis of human skin emanations by gas chromatography/mass spectrometry. 2 . Identification of volatile compounds that are candidate attractants for the yellow fever mosquito (Aedes aegypti). Anal Chem 2000, 72:747-756.

58. Bernier UR, Booth MM, Yost RA: Analysis of human skin emanations by gas chromatography/mass spectrometry. 1. Thermal desorption of attractants for the yellow fever mosquito (Aedes aegypti) from handled Glass beads. Anal Chem 1999, 71:1-7.

59. Savelev SU, Antony-Babu S, Roberts SC, Wang H, Clare AS, Gosling LM Petrie M, Goodfellow M, O'Donnell AG, Ward AC: Individual variation in 3methylbutanal: A putative link between human leukocyte antigen and skin microflora. J Chem Ecol 2008, 34:1253-1257.

60. Perry TL, Hansen S, Diamond S, Bullis B, Mok C, Melancon SB: Volatile fatty acids in normal human physiological fluids. Clin Chim Acta 1970, 29:369-374.

61. Healy TP, Copland MJW: Human sweat and 2-oxopentanoic acid elicid a landing response from Anopheles gambiae. Med Vet Entomol 2000, 14:195-200. 
62. Gallagher M, Wysocki CJ, Leyden JJ, Spielman Al, Sun X: Analyses of volatile organic compounds from human skin. Br J Dermatol 2008, 159:780-791.

63. Penn DJ, Oberzaucher E, Grammer K, Fischer G, Soini HA, Wiesler D, Novotny MV, Dixon SJ, Xu Y, Brereton RG: Individual and gender fingerprints in human body odour. $J R$ Soc Interface 2007, 4:331-340.

\section{doi:10.1186/1475-2875-9-292}

Cite this article as: Smallegange et al: Sugar-fermenting yeast as an organic source of carbon dioxide to attract the malaria mosquito Anopheles gambiae. Malaria Journal 2010 9:292.

Submit your next manuscript to BioMed Central and take full advantage of:

- Convenient online submission

- Thorough peer review

- No space constraints or color figure charges

- Immediate publication on acceptance

- Inclusion in PubMed, CAS, Scopus and Google Scholar

- Research which is freely available for redistribution

Submit your manuscript at www.biomedcentral.com/submit
C Biomed Central 